サント =ジュヌヴィエーヴ図書館の鋳鉄の支柱とゴシック建築の支柱の関係 —1850年前後のパリに建設された 3 つの建築をめぐって——

RELATIONSHIP BETWEEN THE CAST-IRON COLUMNS OF THE SAINTE-GENEVIEVE LIBRARY AND THE COLUMNS OF THE GOTHIC ARCHITECTURE

- Three architectures built around 1850 at Paris-

\author{
加 藤 耕 一* \\ Koichi KATO
}

\begin{abstract}
Designing the Bibliothèque Sainte-Geneviève (BSG), H.Labrouste was inspired by the 13th century gothic architecture which was then renovated into the library of Conservatoire National des Arts et Métiers (CNAM). This paper reveals that the unique slender cast-iron columns of the BSG were influenced by the gothic columns of the CNAM. Right after the BSG, L.-A. Boileau also built the iron church copying the columns of the same gothic architecture. Therefore, it could be concluded that there was an influence of the gothic architecture on the birth of the "architecture" in iron, especially on its cast-iron columns.
\end{abstract}

Keywords : Bibliothèque Sainte-Geneviève, H. Labrouste, L. Vaudoyer, L.-A. Boileau, E. Viollet-le-Duc, Architecture in Iron サント =ジュヌヴィエーヴ図書館、H. ラブルースト、L. ヴオードワイエ、L.A. ボワロー、E. ヴィオレ =ル = デュク、鉄骨造建築

1. 序

1926 年に L. デュベックとP. デスプゼルは、共著『パリの歴史』 において以下のように記した。

$「 1878$ 年頃、人久は鉄骨の建築に救いを見出したと思った……(略)

……乗昼への憧れ、中身の詰まったものに対する空っぽなものの優

越、そして外から見える骨組みの軽やかさは、一つの様式が生まれ ようとしているという期待を抱かせた。この様式の中に、ゴシック 精神の主要なものが、新しい精神と新しい素材によって蘇るかもし れないというのである、〔ところが\}技師たちが 1889 年に機械館と エッフェル塔とを打ち立てたとき、人々は鉄の芸術に見切りをつけ てしまった。だがたぶん、その判断は早すぎだ。」

ここで言及されているのは 1878 年と 1889 年のパリ万博におけ る鉄骨の博覧会建築である。だが本稿は、これに先行する1850年 前後のパリに焦点を定め、そこで修復、改築されていた 1 つのゴシッ

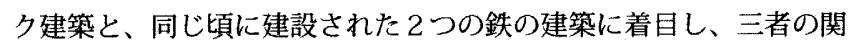
係について考察するものである。

.

\section{2. 本稿の考察対象}

フランスにおける鉄の建築の摇籃を考えるうえで、アンリ・ラブ ルーストのサント = ジュヌヴィエーヴ図書館（1851 年開館）は、 きわめて重要である。むろん、ラブルースト以前のフランスにお
いて、鉄を用いた建築がなかったわけではない2。1786 年には早 くもV.ルイによってテアトル・フランセの小屋組に鍊鉄のトラス が用いられているし、1811 年に建築家 F.-J.ベランジェによって改 築された款物市場においても、技師ブルネによる鉄と銅の混構造の ドームが建設されている3。しかしながらこれらの構造物について S. ギーディオンは以下のように述べる。

「だが少なくともそれは、実際には鉄骨構造というょりは、鉄が使わ れているというだけのものだった。木造の構造を鉄に応用したに過 ぎなかったのである゙。」

これらの建築をフランスの鉄骨建築の前史に位置づけたギーディ オンは、「その後の発展に先行する最初の建物は、アンリ・ラブルー ストによるサント = ジュヌヴィエーヴ図書館である ${ }^{5} 」$ と断言する。

ラブルースト以前、鉄は直接目に触れにくいところで用いられる 場合が多く、例外は鉄橋のような土木構造物か、温室建築のような 19. 世紀前半に登場した新しいビルディング・タイプで見られるの みであり、サント＝ジュヌヴィエーヴ図書館のような記念碑的な建 築で堂々と鉄が用いられることは稀であった ${ }^{6}$ 。ラブルーストのこ の建築の革新性について、B. フーカールは若干大袈装とも思える 表現で次のように述べる。

「真の謎を強調しておくべきであろう。すなわち、建築システムに直
* 東京大学大学院工学系研究科建築学専攻 研究生・博士 (工学)
Researcher, Department of Architecture, Graduate School of Engineering, University of Tokyo, Dr. Eng. 
接的に結びつけられた高度なプログラムのなかでの、システマティッ クな鉄の使用である。先例は存在しない........(略)……もちろん、小 屋組や橋梁、そしていくつかの駅などを思い起こさせることはでき る。しかしながらラブルーストがそこからインスピレーションを受 けた先行例や同時代の直前の実例を見出すことはできない。それこ そが彼の天才であり、䪊である……(略)…ㄷ..のようにして、こ の斬新な表現は、金属によって可能となった円柱の紐さのおかげで、 閱覧室の広さと透明性という2つの要求を满たしたのである ${ }^{7}$ 。」

本稿では、ラブルーストの「建築システム」に踏み込むことはせ ず、主として「金属によって可能となった円柱の細さ!に注目する。 1850 年代、鋳鉄は圧縮に強いという認識から、細い支柱で大空間 を支持する建築がその数を増していた。それらの建築のなかでも、 ラブルーストのサント＝ジュヌヴィエーヴ図書館の原案は、後述す るように 1839 年には既に固まっており、他の鉄の建築と比べても ひときわ早い時期のものであるといえる ${ }^{8}$ 。本稿ではこの建築空間 に影響を与えた先例を、鉄の構造物に求めるのではなく、同時期の パリで修復が進められていたゴシック建築であるサン＝マルタン= デニシャン修道院の食堂に求めようとするものである。

1850 年代は、鉄を用いた建築が一斉に花開いた時代であった。 サントニジュヌヴィエーヴ図書館の開館はロンドンの万博会場とし てクリスタル・パレスが登場したのと同年であったし、その後も、 パリでは 1854 年の中央市場 ${ }^{9} 、 1855$ 年のパリ万博産業宮 (Palais dc I Industrie) ${ }^{10}$ など、鉄の世紀を印象付ける建築が次々に建設されて いった。それらの建築のなかから本稿では、仮設的な新しいビルディ ング・タイプの建築ではなく、モニュメンタルな建築における鉄の 使用という点でサント＝ジュヌヴィエーヴ図書館の後継的存在と位 置づけうるルイ=オーギュスト・ボワローのサントゥージェーヌ教 会堂をとりあげる ${ }^{11}$ 。してフランスで最初の鉄のゴシック・リヴァ イヴァル建築 ${ }^{12}$ となったこの建築が巻き起こした議論のなかに当 時の識者たちの鉄の建築に対する態度を探るとともに、ゴシック建 築と鉄との関係をここでも考察することとする。

\section{3. サント = ジュヌヴィエーヴ図書館と国立工芸学院の図書館}

本稿において先ず注目したいのは、同時期に開館した2つの 図書館建築、サント = ジュヌヴィエーヴ図書館と国立工芸学院 (Conservatoire National des Arts ct Mćticrs) の図書館の類似である。
ラブルーストが鉄を用いて革新的な図書館を建設したのに対し、 もう一方の国立工芸学院の図書館は、ラブルーストの友人であった レオン・ヴォードワイエが 13 世紀のゴシック建築を修復し、そこ に図書館の機能を挿入したものである。

どちらの図書館の閲覧室も、長方形平面を中央の冈柱列によって 2 廊に分割する構成を有している。ラブルーストの閲覧室は天井が 金属の半円アーチによって支觉られたトンネル・ヴォールトで覆わ れ、ヴォードワイエの閲覧室はゴシックのリブ・ヴォールトによっ て覆われている。2 廊を分から円柱は、ラブルーストのものは鋳鉄、 ヴォードワイエのものは石材という相違はあるものの、どちらも極 端に細く背が高いプロポーションを有することから、同様のきわめ て軽やかな印象を作り出している。

これら2つの図書館建築の空閒構成の類似については、オープン の 1 年後に早くも、建築の雑誌 Revue général de l'architecture のディレ クターを務めるセザール・ダリーによって指摘されている。

「かつてのサンニマルタン修道院の食堂の店間が、最近、建築家ヴォー ドワイエ氏の指捕によって修復され、四書館に改造された。この美 しい広間の戈軸方何は……(略)…..際だった軽やかさの円柱の列に よって占められている。閱覧用のテーブルはこれらの門样のあいだ に置かれ、本棚は壁に面して立てられている。この配琶は、学院の

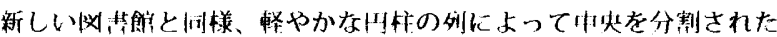
サント =ジュヌヴィエーヴ図書館とのあいだに、大いなるアナロジー を作り出している ${ }^{13}$

しかしながらヴォードワイエによって修復された国立工芸学院の 図書館からサント = ジュヌヴィエーヴ図書館への影響の有無を、ラ ブルースト自身の言説から明らかにすることはできない。彼はこの 建築について、C.ダリーに宛てた手紙において自ら説明しており、 その手紙は Revule général de l'architecture に揭載された。この手紙のな かで、ラブルーストは次のように述べている

「そのうえ、ご死じの通り私は執勧というものが、殊に自らの成果を 語るためにものを蕌くことが好きではありません。また、すでに成 されたことにかまけるというのは私の趣味ではなく、これから成さ れることに取り縄むことの方を好みます。私は分分の後にあるもの よりも㓩にあるものを見ていたい。ですから、すでに 2 年も前に完 成しているサント =ジュヌヴィエーヴ闵制館について、私が語るこ とはほとんどないという柧です ${ }^{14}$

このような書き山しで始まるラブルースト自身によるサントニ ジュヌヴィエーヴ図書館の解説は、決して短いものではないが、こ

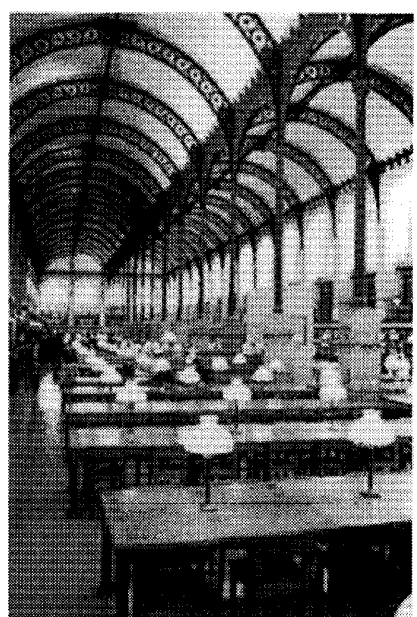

図1：サントニジュヌヴィエーヴ図書館

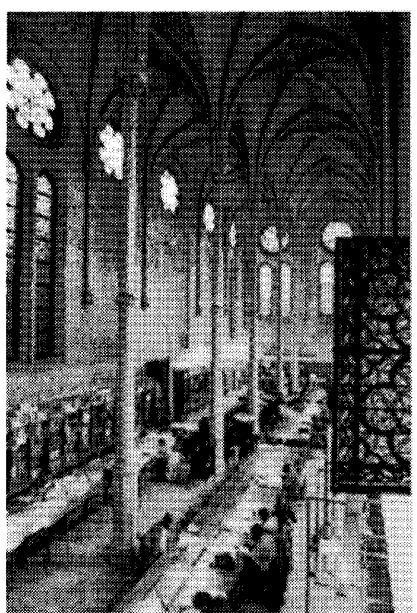

図 2 : 国立工芸学院の図書館

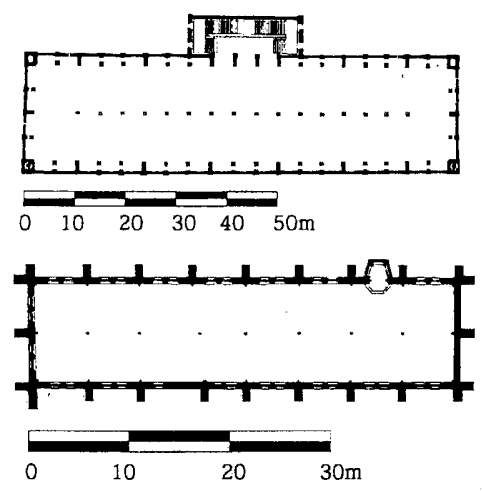

図 3：サント=ジュヌヴィエーヴ図書館、 平面図 (上)

図 4 ：国立工芸学院の図書館、 平面図 (下)

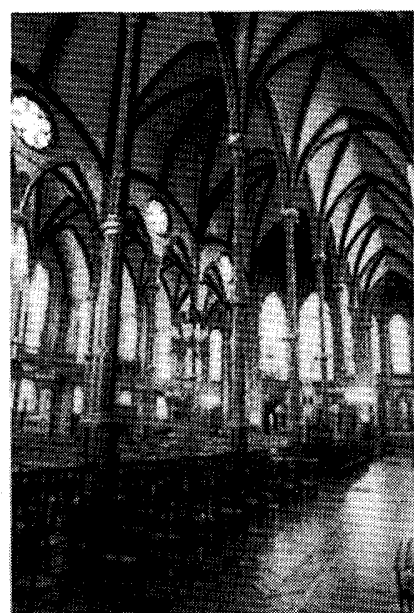

図 5：サントゥージェーヌ教会堂 
の建築の建設の経緯から各部屋の装飾や家具に至るまで、まんべん なく、しかしきわめて簡潔に説明したものであり、後の批評家たち が称賛するもととなった「システマティックな鉄の使用」を取り立 てて詳述するというものではなかった。実際、この建築の中心的な 空間である閲覧室の建築的な説明は以下の段落のみである。

「四書館の2 階に配された大㕕閏は、この建物の全面積を䧗っていま す。すなわち、 $84.75 \mathrm{~m} \times 21 \mathrm{~m}$ であり、1779.75 m²なります。こ の部层へは、鋳鉄の扉から人ります。本は部屋の周国に $5 \mathrm{~m}$ の高さ に並べられ、これが地面から 2.5 m高さにめぐらされた通廊によっ て二分されています。これにより、すべての部分が移動式ハシゴ無 しでアクセス叮能となっているわけです。いくつかの小さな小部屋 が、部屋の周りのヴォールトを受ける控え壁のあいだに設けられて います。この広間は、この空間全体を覆っているヴォールトを受け て支える 18 本の鋳鉄の円柱の連なりによって、2つの平行する身廊 へと分けられています。これらの鋳鉄の円柆は、石の台座の上に立 てられており、それらのあいだには本を収めるための高さ $2.5 \mathrm{~m} の$ キャビネットが置かれています 15 。」

金属による構造を視覚化する鋳鉄の支柱について、ラブルースト は僅か一文で説明するのみである。しかもラブルーストは、その支 柱の数が実際には 16 本であるにも拘わらず 18 本と記述する誤り まで犯している。「すでに成されたことにかまけるというのは私の 趣味ではない」というラブルーストの言葉通り、後世の歴史家たち が絶賛した鉄の構造システムの革新性すら、彼にとってはすでに興 味が失われた過去の出来事に過ぎなかったということであろうか。

続いて以下では、2つの図書館建築の並行関係、類似点などを詳 細に見ていくこととする。

\section{2 つの建築の並行性}

\section{4-1. ラブルーストとヴォードワイエの親交}

アンリ・ラブルースト (1801-75) は、1819 年にエコール・デ・ ボザールに入学し、A.-L.-T. ヴォードワイエと H.ルバのアトリエで 建築を学んだ ${ }^{16}$ 。A.-L.-T. ヴォードワイエの息子レオン・ヴォード ワイエ（1803-72）もまた 1819 年にボザールに入学し、ラブルー ストと同じ、父とその甥が指導するアトリエに入っている ${ }^{17}$ 。ラブ ルーストは 1824 年にはボザールにてグランプリを獲得して 1824 年から 1830 年にかけてイタリアに滞在し、ヴォードワイエは 1826 年にグランプリを獲得して 1827 年から 1832 年にかけてイ タリアに滞在している ${ }^{18}$ 。特に 1827 年kら 28 年にかけて彼ら 2 人は F. デュバン (1823 年グランプリ獲得)、L. デュク（1825 年 グランプリ獲得）とともに 4 人でローマにて活動していた ${ }^{19}$ 。

\section{4-2. $2 つ$ つ建築の時間的な並行性}

1830 年にローマからパリに戻ったラブルーストはイタリアで協

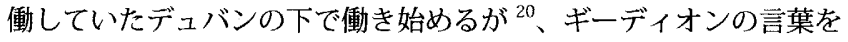
借りれば、「12 年のあいだ、ただ 1 つの建物を任されることもなく

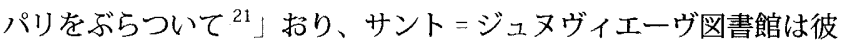
自身が手掛けた最初の本格的な建築作品となった。1838 年 6 月、 ラブルーストはサント = ジュヌヴィエーヴ図書館の建築家に任命 され、10月には同図書館のコレタションのために新しい建物の設 計を命じられる。ラブルーストは、翌 1839 年 12 月 19 日に最初 の設計案を営繥局（Conseil des Bâtiments civils）に提出する。同案は 1840 年 1 月 23 日と 25 日に営繥局によって確認、承認されるが、 フランス下院でのプレゼンテーションは延期された。さらに 1842
年 11 月 21 日には、ラブルーストによる最初の案が再び営繥局に よって承認される。翌 1843 年 4 月 10 日になり漸く下院での承認 が得られ、同年 7 月 19 日に予算が確定、8月 1 日より基礎工事が 始まることになる ${ }^{22}$ 。1 1846 年 3 月には 1 階の組積造部分が完成、 5 月からは 2 階部分の建設が始まり、1847 年の 8 月から 12 月に かけて閲覧室の天井を支える鉄構造が実現した。その後、装飾、調 度品、さらには暖房設備の作業などを経て、1851 年 2 月 4 日にサ ントンジュヌヴィエーヴ図書館は開館した ${ }^{23}$ 。

一方のヴォードワイエもまた、ラブルーストがサント = ジュヌ ヴィエーヴ図書館の建築家に任命されたのと同じ 1838 年 6 月に国 立工芸学院の建築家に任命される ${ }^{24}$ 。彼の最初の設計案はラブルー ストの第 1 案と同じく 1839 年 12 月に提出された。さらに 1843 年 1 月 19 日に提出された案が翌 1844 年 4 月 27 日に承認されて いる。ヴオードワイエが手掛けた国立工芸学院および同美術館の建 築群のうち、本稿で着目している図書館の閲覧室は、1845 年から 49 年にかけてもともと修道院の食堂だったゴシック様式のホール が修復され、1850 年に彩色および絵画による装飾が施された後に、 開館した ${ }^{25}$ 。

\section{4-3. 建築的な類似点}

以上のごとく、これら 2 つ建築は親交のあった 2 人の建築家に よって、まったく同時期に建設されたものであった。フランスで初 の試みであった、純粋に図書館という機能だけのための建築を計画 していたラブルーストが ${ }^{26}$ 、旧友のヴォードワイエが国立工芸学院 の敷地でいかなる図書館を計画しているのか ${ }^{27}$ 、話をしたり現場と なる旧サン =マルタン =デ = シャン修道院の食堂を見学したりした 可能性は否定できない。両閲覧室の空間構成の類似は、すでに見た ように、1852 年にC. ダリーによって指摘されているが、ここでは さらにいくつかの微細な類似点を列挙することとする。

まず重要なのは支柱の細さであろう。C.ダリーも前述の記事に おいて、国立工芸学院の図書館の支柱を「際だった軽やかさの円柱」 (colonne d'une légèreté remarquable) と叙述し、サント =ジュヌヴィ エーヴ図畫館の支柱を同様に「軽やかな円柱」(lćgèrcs colonncs) と 描写している ${ }^{28}$ 。シャフトの基部での直径が $25 \mathrm{~cm}$ 、頂部での直 径が僅かに $18 \mathrm{~cm}$ というサント = ジュヌヴィエーヴ図書館の鋳鉄 の支柱の細さは改めて指摘するまでもないが ${ }^{29}$ 、国立工芸学院の 図書館の支柱もまた、基部で $38 \mathrm{~cm}$ 、頂部で $22 \mathrm{~cm}$ という石造の 支柱としては驚くべき細さを誇っている ${ }^{30}$ 。この支柱については ヴオードワイエ自身も、「並はずれた細さとエレガントさを有する 円柱」(colonnes d'une finesse et d'une élégance extrèmes) と描写してお

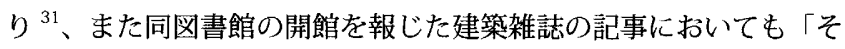
の軽やかさが際だつ 7 本の背の高い細円柱」(sept hautes colonnettes remarquable par leur légèreté) という表現が見られる ${ }^{32}$ 。ヴィオレ= ルニデュクも、これを「著しく背が高く、また極端にかぼそい直径 を有する石造の円柱」(colonnes de pierre d'une hauteur considérable et d' une diamètre extrêmement faible）と描写している ${ }^{33}$ 。

以上のごとく、当時の建築の専門家たちは、一様にこのゴシッ ク建築の支柱の特筆すべき細さを称賛している。このことからも G. ドゥブロックが指摘するように、この細い支柱がラブルースト の鋳鉄の支柱の使用にインスピレーションを与えたと考えることは 十分に可能であろう ${ }^{34}$ 。ラブルーストは、この鋳鉄のコンポジット 
図6(左)：サントニジュヌヴィエーヴ図書館のヴォールト

図7 (右)：国立工芸学院の図書館のヴォールト

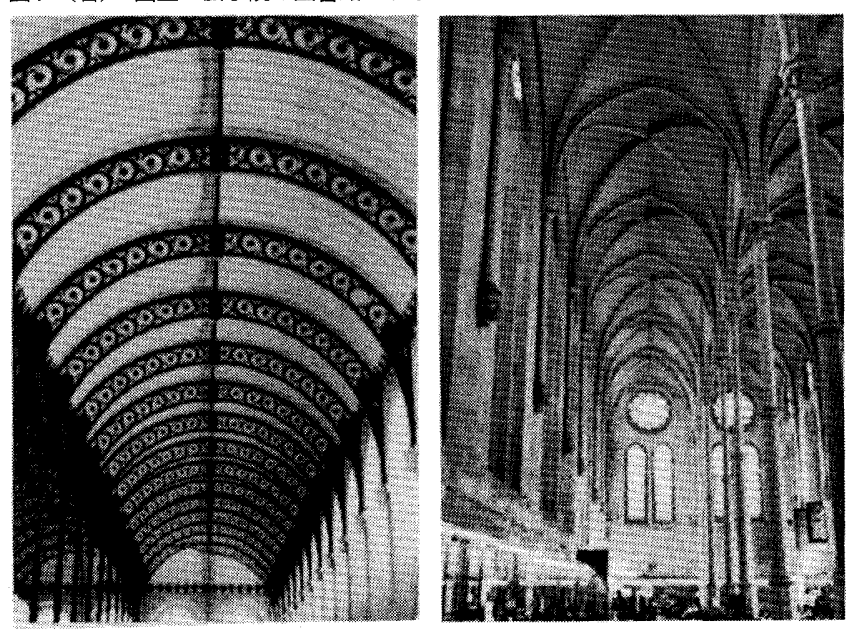

風の細円柱を、閲覧室の大空間の中央にきわめて象徴的に並べた。 この配置もまた、旧サン = マルタン =デ =シャン修道院の食堂から の影響と考えられるわけであるが、これにより極限まで繊細化され た支柱が空間全体に緊張感を与え、明るく軽快な空間の質を作り出 している。このような鋳鉄の支柱の扱いは、先行する鉄骨の構造物 とこの図書館建築とを隔てる重要な点である。そして、そこで用い られている建築言語こそ古典主義様式のそれであるものの、誕生し た空間にはゴシック建築からの影響を見出すことが可能であろう。

$2 つ$ 建築の類似点としてもう 1 点注目すべきは、ヴォールトの 支持方式である（図 $6 \cdot 7$ ）。両者とも、2 廊に分かれた閲覧室の ヴォールト天井を中央の円柱列で受けているが、壁側に目を向け ると、サント = ジュヌヴィエーヴ図書館のヴォールト天井のアーチ は渦巻き状の持送りで支えられていることがわかる。一方、国立工 芸学院の図書館のヴォールトは、壁治いの、あたかも宙に浮いてい るかのようなシャフトで受けられ、そのシャフトはキュ・ド・ラン プと呼ばれるゴシック建築に特有の装飾的な持送りで支えられてい る。この、宙に浮いたシャフトと持送りでヴォールトを支持すると いう構成は、ヴォールトを支持するための堅审な支柱は必要ないと いうことを逆説的に示唆しているかのようであり、このことが、中 央の円柱の細さと相俟ってきわめて軽快な印象を作り出している。

ラブルーストは、1868 年に開館した国立図書館において、石造 の壁体から独立した 16 本の鋳鉄の支柱によって鍊鉄の9つのドー ムを支持する構造を完成させた。ギーディオンはこのことを指して、 「国立図書館に拈いて、ラブルーストはこのシステムを完全なもの にした……(略)……鋳鉄の円柱からなる鉄の骨組みは、壁から独 立して自立している ${ }^{35} 」$ と、サントニジュヌヴィエーヴ図書館から 国立図書館に至る金属の構造システムの進歩を指摘している。た が、金属の構造システムとしては不完全であったとしても、中央の 䋐細な円柱列と壁側の持送りで金属のアーチを受けるサント =ジュ ヌヴィエーヴ図書館のデザインは、国立図書館と同様の軽快な印象 を作り出すことについて、すでに成功しているといえよう。そして ラブルーストが鉄を用いた建築の最初の試みにおいて、金属の支柱 ではなく持送りでアーチを受けるという特異な構造形式を採用した 背景に、ヴォードワイエが修復に取り組んでいたゴシック建築から の影響を見ることも可能であると考えられる。
以上のごとく、ラブルーストのサント = ジュヌヴィエーヴ図書館 とヴオードワイエの国立工芸学院の図書館のあいだの直接的な影響 関係こそ明らかにできないものの、両者のあいだに何らかの影響関 係があった可能性は高い ${ }^{36}$ 。ラブルーストが考案した、鋳鉄の支柱 が軽々とヴォールトを支える空間構成は、ラブルースト自身のプロ ジェクトを遡って探してみても先例がなく ${ }^{37} 、 こ の 13$ 世紀のゴシッ ク建築からインスピレーションを受けた可能性は高いといえよう。

続いて以下では、サント = ジュヌヴィエーヴ図書館の開館 4 年 後に，同じくパリに建設された鋳鉄の支柱を持つ建築、サントゥー ジェーヌ教会堂と、上述の2つの建築との関係を考察する。

\section{L.-A. ボワローのサントゥージェーヌ教会堂}

建築家ルイ = オーギュスト・ボワロー (1812-1896 年) は、B.フー カールも指摘している通り、建築の歴史のなかでその名が重視され ることはほとんどなかった ${ }^{38}$ 。その息子であるルイ = シャルル・ボ ワロー（1837-1914）の方がまだしも、技師ギュスターヴ・エッフェ ルとともにパリ最古の百貨店建築ボン・マルシェを手掛けた建築家 として、その名が知られているといえよう ${ }^{39}$ 。ボン・マルシェ百貨 店（1876 年）もまた、その大規模な鉄骨構造は鉄の建築の歴史を 考える上で重要であるが、先に建築における鉄の可能性に気づき、 理論化、実践したのは父ルイ =オーギュスト・ボワローであった。

1812 年にパリで生まれた L.-A. ボワローは、人生の前半を木工 職人として過ごした。木工職人として被が手掛けた作品には、コン ピエーニュのサンタントワーヌ教会堂の説教壇（1834-37 年)、パ リのサン = ジェルマン = ロクセロワ教会堂のパイプオルガンの外装 箱 $(1839$ 年)、エール = シュル = ラ・リスのサン = ピエール教会 堂の内陣仕切（1840-42 年）などが挙げられる ${ }^{40} 。$

その彼が人生の半ばにして初めて手掛けた建築作品がパリのサン トゥージェーヌ教会堂（1854-55 年）である。ゴシック様式を模 して建てられたこの建築は、外壁こそ石造であるものの、支柱やリ ブといった骨組みから天井に至るまで、すべてに鉄が用いられ、鉄 を用いたゴシック建築の可能性が極限まで追求されたものになって いる ${ }^{41}$ 。この建築に着手する前年、ボワローは建築における鉄の可 能性を論じた『新たなる建築形態 ${ }^{42}$ を発表しており、サントウー ジェーヌ教会堂はその実践とも位置づけられるものであった。

教会堂は交差廊を有さない 5 廊式の長方形平面であり、中央の身 廊は幅 $10 \mathrm{~m} 、$ 六分ヴオールトが 4 回絽り返される 8 ベイからなる。 その両脇の側榔は幅 $5 \mathrm{~m}$ 、もっとも外側の側廊だけは 2 層になって おり、幅 $2.5 \mathrm{~m}$ で 1 階部分はチャペルのような役割を果たしている。

\section{6. サントゥージェーヌ教会堂をめぐる論争}

このサントウージェーヌ教会堂をめぐっては、ヴィオレ =ル = デュクとボワローとのあいだに激しい論争が巻き起こった ${ }^{43}$ 。論争 の発端となったのは、理工学校の出身でサン・シモン主義の経済 学者として知られるミシェル・シュヴァリエ（1806-1879 年）の 記事であった。1855 年のパリ万博に関連して 1855 年 6 月に発表 された「万国博覧会：記念碑的建造物に使用された鉄と鋳鉄」と題 されたこの記事中でシュヴァリエは、同年 12 月に竣工することに なる、記事の発表時は建設中であったボワローのサントゥージェー 邓教会堂を大きく採り上げ、これを称賛した ${ }^{44}$ 。シュヴァリエは以 
下のようにこの建築を紹介する。

「好事家たちは、クリスタル・パレスの内部だけにではなく、パリの 城壁の内側にも、鋳鉄と鉄のモニュメンタルな別の建物を見ること ができる……(略)……サトゥージェーヌ教会堂である。建築家ボ ワロー氏は、ゴシックの形態を採用し、それがこの新しく日覚まし い材料に、ここではよく適応していた ${ }^{45}$ 。」

シュヴァリエがクリスタル・パレスと対比してサントゥージェー ヌ教会堂に言及していることは注目に值するが、本稿においては、 シュヴァリエの以下の記述が一層興味深い。

「ボワロー氏は、サントゥージェーヌ教会堂において、ゴシック様式 を、特にリブ・ヴオールトを完全に再現しながら、人䙺模に鉄と鋳 鉄を導入した。石材は外側の仕切り壁に用いられたのみである。内 部は完全に鋳鉄と鉄だけで作られており、それは大井さえも同様で ある。支柱は鋳鉄製で、旧サン = マルタン＝デ =シャン修道院の食堂、 見在の工芸学院の図書館のヴォールトを支持する石造の円柱をモデ ルとしている。その直径の平均は $32 \mathrm{~cm}$ であり …....(後略 $)^{46}$

ここでシュヴァリエが指摘している通り、サントウージェーヌ教 会堂の支柱は、八角形の背の高い台座の上に置かれ、その円柱の高 さの中間付近で、剞型装飾の施されたリングによって上下に二分さ れるという、サン = マルタン = デ = シャン修道院の支柱のデザイン をコピーしたものとなっている。すなわちこの建築は、ヴォードワ イエによって修復されたばかりの国立工芸学院の影響を受けた建築 と位置づけることができるものなのである。

シュヴァリエの論説において、サントゥージェーヌ教会堂は全 体として、鉄とゴシック様式の融合がもたらした、その経済性ゆえ に高く評価されていた。ところが、この記事に即座に反応して激 しい調子で反論したのがヴィオレ=ルンデュクであった。彼は雑誌 Encyclopédie d'architecture のディレクター、A. ランスに宛てた手紙 という形で反論を著し、これは直ちに同誌の 1855 年 6 月号の巻頭 記事として揭載された ${ }^{47}$ 。シュヴァリエが賛美する鉄と鋳鉄の建築 について、ヴィオレ =ル =デュクの意見は以下のようなものであっ た。すなわち、巨大建造物における金属の使用の可能性を認めない わけではない。それらはすでに、鉄道駅や市場の大部分を覆ってい る。「しかしそれらの建造物は、際限なく繰り返すことのできる単 一の形態にのみ適応可能な、きわめて単純な平面を有する倉庫でし かない、ということを忘れてはならない ${ }^{48}$ 。」

さらに、シュヴァリエが鉄を用いた教会建築を称賛したことを受 けて、ヴィオレ =ル =デュクはサントゥージェーヌ教会堂を、さら にはボワロー個人をも攻撃しはじめる。

「少なくとも一般大衆や聖職者たちがこの建物の内部に大り、これを モデルとして示すことができるようになるまでは待った方が良い。 この混合建築の考案者による図面を見る限り、この構造物の寿命に ついて、我人は大きな信頼感を感じることができない。外観につい てどうかというと、それは美しくない ${ }^{49} 。 」$

この教会堂はこの年の 12 月に竣工したため、ヴィオレ = ル = デュ クはこの時点では内部を見ることなく、その外観は美しくないと断 言したわけであるが、そのボワローに対する態度はきわめて攻撃的 であるといえよう。だが彼の攻撃はこれにとどまらない。

「サントゥージェーヌ教会堂の建設の指揮を執るボワロー氏は、何ら かの技術者ではあるかもしれないが、建築家ではない。彼はもとは、 非常に腕の良い木に:緗1職人だったのであり、例えどのような経験
を積んできたとしても、それは建築の実践的な初等教育に変わるも のではないのである ${ }^{50}$ 。

このように 2 歳年長のボワローに対するヴィオレ = ル = デュク の嘲罵は菏烈をきわめている。ボワローも即座にA. ランスに宛 ててヴィオレ =ル = デュクに対する反論を著し、Encyclopédie d architecture の 1855 年 7 月号に揭載されるが、ランスの計らいによ り、そこにはボワローの手紙に対するヴィオレ =ル =デュクの再反 論も同時に掲載された ${ }^{51}$ 。

個人攻撃にまで発展したヴィオレンルニデュクの批判に対する ボワローの反論を悉に見ていくことは本稿の意図するところではな い。鉄の建築の歴史を考える上で重要なのは、ヴィオレ = ル = デュ クの最初の手紙に書かれた以下の一節と、その部分に対するボワ ローの反論である。ヴィオレニルニデュクは「外観についてどうか というと、それは美しくない」に続いて以下のように述べる。

「我々には以下のように思われる。この仕事によって建てられた大建 造物は、太陽の方角や気温の変化に応じて、絶元間ない工事を必要 とするであろう。そしてまたこの仕事は、特に都合良く拙劣に金属 と混合された优造部分は、早々に倒壇することになるであろう。な ぜならば鉄と不積みとが調和していないからである。切り妻の頂部 に受けられている鉄のアーチは満足のゆくバランスをとっておらず、 そして最終的に、そのすべての堅军性が組み立ての極端なまでの正 確さの内に存在するこのシステムは、建築家の技術よりも機械家の 技術に近いものなのである ${ }^{52}$ 。

これに対してボワローは次のように反論する。

「そのうえ、この批評家が言うように、比較対象が足りないわけでな い。汞物市場の鉄のドームが完成したのは咋日のことではない。サ ント =ジュヌヴィエーヴ図書館の大ホール、数多くの鉄道の駅、ア ンヴェールの証券取引所、その他多くの金属の構築物が、[金属の] 恐ろしい膨張の効果やその他の我々を脅かすものについて、すでに 我々を安心させている……(後略 $)^{53} 」([$ ]内は筆者による補足)

ボワローの反論中、サント = ジュヌヴィエーヴ図書館に言及して いるのはこの 1 箇所のみである。だが、これに対してヴィオレ = ル =デュクは、その再反論で過敏ともいうべき反応を示している。

「我人は最初から、鉄道の駅や市場などの层根に金属が用いられてい ることに言及している。そして単純な平面構成の建造物における金 属の使用は、その有用性ゆえに定着したと指摘している。にもかか わらず何故、ボワロー氏は次の一文によって、我々をこの主題に引 き戻そうというのであろうか。『そのうえ、この〈批評家〉（私のこ とである）が言うように、比較対象が足りないわけでない……』そ

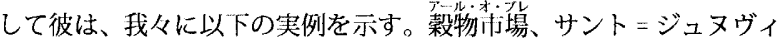
エーヴ図書館、鉄道駅など。これらの建造物とボワロー氏の積層す るドームで構成されるシステム ${ }^{54}$ とのあいだに、いかなる関係が あるというのか。ボワロー氏は、彼と同様に我々も称賛するサント シジュヌヴィエーヴ図書館の屋根と同じような屋根を作ったからと いって、自らを䪊者であると主張しているのであろうか。何故ボ ワロ一氏は、我々が攻撃していない建物を拠り所にしようというの か。いかなる目的で彼は、我々が被を H. ラブルースト氏と同じ水淮 に置こうとしていると趴解させようとするのか。それは我々の意図 するところではない ${ }^{55}$ す」

ボワローがサント＝ジュヌヴィエーヴ図書館の名を挙げたことに 対するヴィオレ =ル =デュクの過剩とも思えるこの反応は興味哚 い。この論争が交わされた 4 年前に開館したサント =ジュヌヴィ エーヴ図書館は、ヴィオレ = ル =デュクにとってもそれだけ革新的 
な建築であったということであろう。あるいは、彼はボワローの本 心を見抜いていたのかもしれない。サント＝ジュヌヴィエーヴ図書 館の開館以降、1850 年代のパリでは中央市場やパリ万博の産業宮 など巨大な鉄骨建築が登場するが、それらはいずれもヴィオレ = ル ニデュクが「きわめて単純な平面を有する倉庫でしかない」と断じ たビルディング・タイプであった。サント＝ジュヌヴィエーヴ図書 館に続くモニュメントはサントゥージェーヌ教会堂に他ならないと いう自負が、ボワローの胸中になかったとはいえまい。実際にその ような位置づけが可能な建築であるからこそ、ヴィオレ =ル = デュ クはここまで辛辣な批判を浴びせたのではなかろうか。

他方、ボワローがその教会堂の支柱のデザインをサン = マルタン ニデ = シャン修道院の食堂から引用したことについて、ヴィオレ ニル =デュクは多くを語らない。唯一の言及は、ボワローが彼の著 述『新たなる建築形態ににおいて、一般に鋳鉄は石材のためのデザ インをコピーするためのものと考えられているが自分はその逆を行 く、と宣言していることとの矛盾を批判した箇所のみである ${ }^{56}$ 。ま たボワローがその支柱のモデルとして、サン = マルタン = デ = シャ ン修道院の食堂の支柱を選んだことについての、ヴィオレ = ル = デュク自身の見解は存在しない。

ところが、この論争の 2 年後の 1857 年に出版されたヴィオレ ルンデュクの゙『世建築辞典』の第 3 巻には、興味深い記述が見ら れる。辞典中、「円柱」に関する項目で、彼はサン=マルタン =デ シシャン修道院の食堂の支柱に言及する。

$\ulcorner 13$ 世紀の初めにはなお、付柱のない門筒鬥の円柱が什いられ、こ の時代の建築家たちの方針により、文朴と文柱とのあいだに可能な 限り大きな空渻が残されるように、材料の質が許す範进でその直往 を小さくしょうと努められた。それはしたがって、同じようなケー

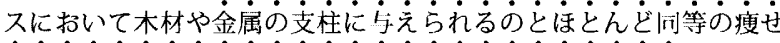

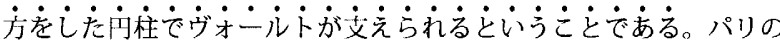

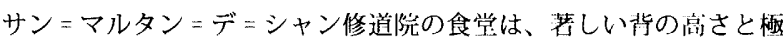
端にかぼそい直径を持つこのような不造の冈柱の、我从に残された 最良の実例の 1 つである。しかしこれは、八角形の土台のトに溯か れ、その円柱の高さの中間付近で䇏型で装飾されたリングで2つに 分けられるという功みな構成により、その過度な瘦せ方に甘がショッ クを受けないように、またそれらの网柱がそのラッパ型の杜頭の! に2列のヴォールトを支えるのに、実際通り允分な強度を持ってい るように見せている ${ }^{57}$ 。」(傍点笋者)

ヴィオレニルニデュクがここで円柱を形容した「かぼそい (faible)、「瘦せ方」(maigreur) といった表現は、その数年前に批評 家たちや建築家ヴォードワイエ自身が同じ円柱を形容した「軽やか さ」(légèreté)、「細さとエレガントさ」(finesse et élégance) といっ た表現と比較したとき、必ずしもこれを称賛しているわけではない ようにも見える。しかしながら、「金属の支柱と同等の溲せ方」を 持つ 13 世紀のゴシック建築の支柱のなかでも、サン = マルタン = デニシャン修道院の食堂の円柱の構成については、ゴシック建築の 大需ヴィオレ = ル = デュクならではの高い評価を与えていることが わかる。だが、この評価をボワローのサントゥージェーヌ教会堂の 鋳鉄の支柱に照らし合わせてみると、ボワローがその支柱のデザイ ンのモデルにサンニマルタン = デ = シャン修道院の食堂のそれを 選択したことは、ヴィオレ =ル =デュクにとっても道理にかなって いたといえよう。しかしながら彼はこの点においてもボワローを評 価することはなく、ただ批判を浴びせるのみであったため、『中世
建築辞典』を執筆したときにボワローの鋳鉄の支柱を念頭に置いて いたかどうかは不明である。他方ボワロー自身も、いかなる理由で 国立工芸学院の図書館として再生したばかりのサン = マルタン = デ = シャン修道院の食堂の支柱をモデルとしたのかということについ て、この論争の時点では沈黙している ${ }^{58}$ 。

1850 年代のパリにおいて、国立工芸学院の図書館の開館は決し て些細な出来事ではなかったが、当然参照されるべきというほどの 大事件でもなかった。当時は、様々な側面で中世建築の再評価が成 された時期であったが 59 、サン = マルタン =デ = シャン修道院の食 堂は名作であるとしても小品に過ぎなかった。ヴィオレ = ル =デュ クの『中世建築辞典』での評価に先立って、ボワローがサン = マル タン = デ = シャン修道院の食堂の円柱をモデルとして鋳鉄の支柱を デザインしたとき、純粋に優れたゴシック建築としてこれを参照し たとは考えがたい。彼はその背後にサント = ジュヌヴィエーヴ図書 館を見てはいなかったであろうか。れまで再々参照してきた通り、 2 つの図書館建築の類似は 1852 年にはすでに建築雑誌上で指摘さ れていた。したがって、ヴィオレニルニデュクが敵愾心もあらわに 示唆したように、ボワローが自らをラブルーストの後継的な䩢新者 だとみなしていたとすれば、彼が鉄のゴシック建築を企図する上で サントニジュヌヴィエーヴ図書館との類似が指摘されているゴシッ ク建築を参照したという可能性は十分に考えられるのである。

\section{7. 結}

国立工芸学院の図書館からサント = ジュヌヴィエーヴ図書館への 影響については、その平面構成の類似がこれまでにもたびたび指摘 されてきた。本稿はここに、平面構成の影響ばかりでなく、新しい 素材と構造によって将に誕生せんとしている新しい建築空間への、 ゴシック様式からの影響を見出したものである。これら2つの図書 館建築のあいだでゴシック建築から鉄骨建築への翻案が成されたと き、そこでは平面構成ばかりではなく、支柱の繊細さとその緊張感 によって生じる軽快な空間の質も重要であったと考光られる。その ことは、サントゥージェーヌ教会堂において、国立工芸学院の図書 館のゴシックの支柱が鋳鉄でコピーされて用いられたという事実か らも確認できよう。鉄の建築はその黎明期において、ゴシックの支 柱の細さを鋳鉄の技術によって容易に獲得しながら、新しい時代の 軽やかな空間を作り上げていったものと考えられる。

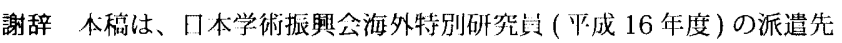
での㸴究活動の・部をなすものです。䛉して㴬觉を衣します。

1 Lucien DUBECH et Piere D'ESPEZEL, Histoire de Paris, Payot : Paris, 1926, p.464. の一節はW.ベンヤミンの『パサージュ論!として知られる一連の覚え青き にも、「鉄肖建築」のカラゴリーのなかで引州されている。本文中の引用は、

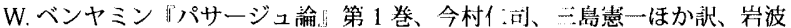
現代文速、2003 年、p.369、[F4a,5] による。

2 ラブルースト以前のフランスにおける鉄を用いた主要な構造物としては、テ アトル・フランセ（1786 年）、ポン・デザール（1801 年）、款物市場（1811 年）、マドレーヌの市場（1824-38 年)、ギャルリー・ドルレアン（1829-31 年)、パリ植物園の温室 $(1834-36$ 年)、パリ = ヴェルサイユ路線の鉄道車 庫（1837 年以降）などが挙げられる（Bertrand LEMOINE, L'architecture du fer. France : XIX' siècle, Édition du Champ Vallon, 1986.)。

3 Sigfried GIEDION, Building in France, Building in Iron, Building in Ferroconcrete, trans J. Duncan Berry, The Getty Center, 1995, pp.103-104.

4 ibid., p.104.

5 ibid., p.103.

6 木稿では 19 世紀に登場した鉄とガラスの〈仮設的な〉ビルディングタイプに 
対立する概念として「モニュメンント」を用いた。当時の「モニュメント」の 概念を澉密に定義するには、それだけでも一編の論考が必要にならうが、こ こでは仮設的な鉄の構造物に対比して、永続的な建筑を指すものとする。

7 Bruno FOUCAR'T, “Henri Labrouste et ses contemporains”, Les monttments historiques de la France, t.6, 1975, p.7

8 1824-38 年にはすでにパリでマドレーヌ市場が建設されており、鋳鉄の支柱 の使用自体は、必ずしもラブルーストが最初というわけではない。

9 V.バルタールが最初に手掛けた石造の中央门場は 1853 年にナポレオン三世 の命により建設途中で取り買され、1854 年より鉄とガラスの新しい中央市 場が建設された (Haussmann, Mémoires, Seuil, 2000, pp.1072-1073)。

10 技師のバローとブリデルによって設部された万博会場。1900 年のパリ万博 の際、新会場の建設のために取り壊された (B. LEMOINE, Op.Cit.,pp.219-220)。

11 B. フーカールもまた、「ラブルーストの真の弟子はルイーオーギュスト・ボ ワローであろう」と指摘している (B. FOUCART, Op. Cit.,p.8)。

12 イギリスでは 1813-18 年に、T.リックマンによって3 棟の鋳鉄製ネオ・ゴ シックの教会堂が建設されている (B. LEMOINE, Op. Cit., p.173)。イギリスと 比してフランスのゴシック・リヴァイヴァルは修復の側面が強かったと考え られるが、鉄に注目しても、シャルトル大聖堂の小屋組（1837）やルーアン 大埕堂の尖塔（1837-63）などの修復において、早くから鉄が用いられていた。

13 César DALY, "Réfectoire de l'Abbaye de Saint-Martin", Revue général de l'architecture, t.10, 1852, p.62. 両者の類似については、その後の建築史研究においても しばしば指摘されている。(B. LEMOINE, Op. Cit., p.238 ; Barry BERGDOLL, Leon Vaudoyer. Historicism in the Age of Industry, MIT Press, 1994, p.165. ; Geneviève DEBLOCK, "Le Conservatoire national des arts et métiers", Myriam BACHA et Christian HOTTIN (dir.), Les bibliothèques parisiennes : architecture et decors, Paris, 2002, p.146.) 他方、D.V. ザンテンは雨者のあいだに構造的な関係はないと主張す る (David Van ZANTEN, Designing Paris. The Architecture of Dubun, Labrouste, Duc, and Vaudoyer, MIT Press, 1987, p.98.)。

14 Henri LABROUSTE, “à M. le Directeur de la Revue d'architecture", Revue général de l" architecture, t.10, n.11-12, 1852, p.381.

15 ibid., p.382.

16 Henri DELABORIE, Notice sur la vie et les ouvrages de M. Henti Labrouste, Paris, 1878, p.6; Pierre SADDY, Henri Labrouste architecte 1801-1875, Caisse Nationale des Monuments Historiques et des Sites : Paris, 1977, p.4 ; Visions. Bibliothèque SainteGeneviève. Catalogue de l'exposition "Voir et revoir l'œuvre de Labrouste", 11 octobre - 9 novembre 2001, Bibliothèque Sainte-Geneviève : Paris, 2002, p.7.

17 B. BERGDOLL, Léon Vaudoyer, pp.43-44 ; B. BERGDOLL, Les Vaudoyer. Une dynastie d' architecture, Éditions de la Réunion des musées nationaux, 1991, p.33.

18 P.SADDY, Op.Cit., p.8, Visions, pp.7-8 ; B.BERGDOLL, Les Vaudoyer, p.40

19 D.V.ZANTEN, Op. Cit., p.4

20 Leon Labrouste, La bibliothèque nationale. Ses batiments et ses constructions, Paris, 1885, p.45.

21 S.GIEDION, Op.Cit., p.106.

22 D. v. ZAN'TEN, Op.Cit., p. $89 ;$ Visions, p.9.

23 Visions, p.10

24 Louis ANDRÉ, "Léon Vaudoyer et le Conservatoire des arts et métiers", La revue : Musée des arts et métiers, n.16, septembre 1996, p.37.

25 B. BERGDOLL, Lén Vaudoyer, pp. $165-166$

26 「図書館としてのみ役立てられる公共の建築が建設されたのは、フランス において初めてのことであった。」(César DALY, “Des bibliothèques publiques”, Revue général de l'architecture, t.8, n.11-12, 1849-50, p.416.)

27 国立工芸学院は、占オードワイエ以前から 40 年にもわたって前任の建築 家たちによって計画され続けていた。旧サン＝マルタン＝デ =シャン修道 院が修道院長グレゴワールの発案により国立工坛学院に転用されることが 決定したのは 1794 年。この建築計西に最初に携わった建築家 F.ドラノワ (1798-99 年、在任)による計画図面によれば、修道院の食堂は取り壊される ことになっている。しかしながら続いてこの任に就いた建築家 C.-J.-B. ジャイ エ (1800-06 年、在任) は、敷地内の多くの古い建築群を取り壊したものの、 経済的な理由から食堂の取り壊しを断念した。以降、この食堂は保存される こととなり、その後の建築家 A.M.ペイール (1806-32 年、在任)、V.デュボ ワ(1832-38 年、在任)を経て、ヴォードワイエ (1838-72、在任) の下で図 書館として生まれ変わった。（B. BERGDOLL, Léon Vaudoyer, pp.142-167.)

28 C. DALY, Op.Cit., p.62.

29 Encyclopedie d'architecture, t.3, 1853, P.28. 円柱の高さは約 $4.5 \mathrm{~m}$ 。

30 G. DEBLOCK, Op.Cit., p.145. 円柱の高さは約 $8.2 \mathrm{~m}$

31 L'on VAUDOYER, "Études d'architecture en France : Couvents et abbayes", Magasin Pittoresque, t.8, 1840, p.167.

32 Adolph LANCE, "Conservatoire des arts et métiers. Ouverture de la bibliothèque", Moniteur des architectes, t.5, 1852, pp. 3-6.

33 E.E. VIOLLET-LE-DUC, "Colonne", Dictionnaire raisonné de l'architecture française du XI' au XVI' siècle, t.3, 1857, p.497.

34 G.DEBLOCK, Op.Cit.,p.146.

35 S. GIEDION, Op.Cit., p.107.

36 両者のあいだの影響関係を示すものの一つとして、ガス灯による照明を挙げ
る先行研究もある。「講屚と同じくこの网書館も、液間も開館することにな っていたため、わずか 2 年前のラブルーストのサント =ジュヌヴィエーヴ汹 書館が先駆となった、ガス照明のための潐借が成された。(B. BERGDOLL L'on Vaudoyer, p.167.) ここで指摘されているのはラブルーストからヴォードウ イエへの影響であるが、同時期に同じ四書館建築を手掛けていた 2 人の建築 家のあいだに交流があったことを示す傍証のつにはならう。

37 唯一、サントニジュヌヴィエーヴ図書館の鋳鉄の支柱に似た形態を有するも のとしては、ラブルーストが 1836 年から 1840 年にかけて手掛けたコンコ ルド橋の街灯デザインが举げられる（拙稿、「19 世紀パリにおけるガス灯の 導入と、建築家による街火丁デザイン一鋳鉄の山样の誕牛一一、2006 年度大 会学術講演梗概集 F-2、pp.199-200)。

38 Bruno FOUCART, "La "Cathédrale synthétique» de Louis-Auguste Boileau", Revute de l" art, n.3, 1969 , p.49.

39 S.GIEDION, Op.Cit., p.115-119. ただし同書では、鉄骨の建築に関する初期の 重要な著作として、Louis-Augustc BOILEAU, Le fer, principal element constriuctif de la nouvelle architecure, Paris, 1871. が紹介されており、1855 年のパリ万博産 業宮と同年に建設されたサントゥージェーメ教会堂にも触れられている（S GIEDION, Op.Cit., pp.103, 124.)

40 Bernard MARREY (présentation de), La querelle du fer. Eugène Viollet-le-Duc contre Louis Auguste Boileau, Édition du Linteau : Paris, 2002, p.117.

41 同時期のイギリスでも鉄骨のゴシック・リヴァイヴァル建築、ディーン\&ウ ッドワード事務所によるオックスフォード大学博物館が誕生している。鋳鉄 の支柱が立ち立び、ガラスのトップライトから明るい光が降り注ぐ中庭空間 は、ボワローのサントゥージェーヌ教会堂が鉄という材料を用いながらも。 あくまで石造のゴシック建築を模したのと対照的に、きわめて近代的な空間 となっている。オックスフォード大学博物館は 1854 年にコンペで設計者が 決定し、1855 年6月に着工、1860 年に完成しているので、ボワローの方が 僅かに先行していることになる。B.ハワードは、この建築が、1853 年に The Builder誌上でイギリスに紹介されたサントニジュヌヴィエー方図書館ときわ めて近い精神を有していると指摘している (Birkin HAWARD, Oxford University Museum. Its architecture and art, Oxford University Museum, 1991, p.10)。

42 L-A. BOILEAU, Nouvelle forme architecturale, Paris, 1853.

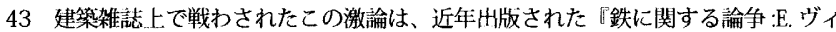
オレニルンデュク対 L.A. ボワロー』に再録されている。(B. MARREY,Op.Cit.)

44 Journal des Débats, ler juin 1855. (B. MARREY, Op.Cit., pp.56-76 に再録)

45 B. MARREY, Op.Cit., p.68.

46 ibid., p.69.

47 VIOLLET-LE-DUC, "A M. Adolphe Lance", Encyclopedie d'architecture, t.5, n.6, 1855, pp. $81-87$ (B.MARREY, Op.Cit., 78-86 に再録) .

48 B. MARREY, Op.Cit., p. 81 .

49 ibid.,p.82. ヴィィオレニルニデュクが石材と鉄の混構造のアイディアを図面で発 表したのは 1864 年の『建築講話』の補図と 1872 年の『建築講話』第 2 巻 においてであり、したがってボワローの10 年以上後のことである。

50 ibid., p.83.

51 L-A.Boileau, Encyclopédie d'architecture, t.5, n.7, 1855, pp.100-105. ; E.E.Viollet-le-Duc, Encyclopedie d'architecurre, t.5, n.7, 1855, pp.105-110 (B.MARREY, Op.Cit., pp. 87-97, 98-107 に再録。

52 B. MARREY, $o p . C i t$., pp. $82-83$

53 B. MARREY, Op.Cit., p. 94 .

54 L.-A. BOILEAU, Nouvelle forme architecturale, Paris, 1853. で提唱された «composition synthéthique» のこと。

55 B. MARREY, Op.Cit., p.105.

56 ibid., p.103.

57 VIOLLETT-LE-DUC, "Colonne", Dictionnaire raisonné... , t.3, 1857, p.497.

581886 年に発表された Histoire critique de l'invention en architecture で、ボワローは 次のように説明している。「独立柱の場合、中世の工匠たちの離れ業によって 石材で成し遂げられた類い希な型が、完全に鋳鉄に適用可能なモデルを提供 している。旧サン = マルタン =デ = シャンの食堂（現国立工芸学院の図書館） の不で作られた単円柱は、その金属のような振舞いの扔かげで、もしそれが 鋳鉄で再現されたならば、鉄骨の規模にきわめて相応しいように思われる。 そしてそのことは、サントゥージェーヌにおいて正しいと認められた。」(L-A. BOILEAU, Histoire critique de linvention en architecture, 1886, p.134.）この文章には、 ヴィオレ = ルニデュクによる『中世建築辞典』におけるサン＝マルタン = デ シシャンの食堂の川柱に対する評価が反映されている叮能性があるう。

59 V.ユゴーの『ノートル =ダム・ド・パリ』(1831 年) やヴィオレ = ル = デュ クによるヴェズレーのマドレーヌ教会堂の修復 (1840 年〜)、パリのノート ル = ダム大聖堂の修復 (1842 年にコンペ、1845 年から修復開始) など。

本文中の写真は筆者撮影。また図 3 は Encyclopédic d'architecture, t.1, 1850, Pl.71 によ り、図 4 は J.-B.-A. LASSUS, [Abbaye de Saint-Martin-des-Champs] Plan du refectoire, BNF Richelieu Estampes et photographies, 1835 により、筆者作図。

（2005年12月 5 日原稿受理，2006年10月 5 日採用決定） 